ISSN: 2302-8556

\title{
Pengaruh Efektivitas Sistem Informasi Akuntansi pada Kinerja Individual dengan Budaya Organisasi sebagai Pemoderasi
}

\author{
Dewa Ayu Ari Arma Bintang ${ }^{1}$ \\ Ida Bagus Dharmadiaksa ${ }^{2}$
}

${ }^{1}$ Fakultas Ekonomi dan Bisnis Universitas Udayana (Unud), Bali, Indonesia email: armabintang@gmail.com / Telp: 082237628809

${ }^{2}$ Fakultas Ekonomi dan Bisnis Universitas Udayana (Unud), Bali, Indonesia

\begin{abstract}
ABSTRAK
Teknologi informasi saat ini bukan menjadi tuntutan lagi bagi perusahaan atau organisasi, melainkan sudah menjadi kebutuhan untuk menunjukkan kerja entitas perusahaan atau organisasi tersebut. Peranan budaya organisasi diharapkan dapat merangsang disiplin kerja karyawan, agar dapat meningkatkan produktivitas dan prestasi kerja karyawan sehingga tujuan suatu perusahaan dapat diwujudkan. Penelitian ini bertujuan untuk mengetahui pengaruh efektivitas sistem informasi akuntansi pada kinerja individual dengan budaya organisasi sebagai pemoderasi di Lembaga Perkreditan Desa Kecamatan Tegallalang. Populasi dalam penelitian ini berjumlah 132 populasi. Metode penentuan sampel menggunakan teknik sampling jenuh sehingga didapat jumlah sampel sebanyak 132 orang. Teknik analisis data menggunakan Uji Moderating Regression Analysis (MRA). Hasil pengujian hipotesis pertama menunjukkan bahwa variabel efektivitas sistem informasi akuntansi berpengaruh positif pada kinerja individual. Hasil pengujian hipotesis kedua menunjukkan bahwa budaya organisasi sebagai pemoderasi mampu memerkuat pengaruh efektivitas sistem informasi akuntansi pada kinerja individual.
\end{abstract}

Kata kunci: efektivitas sistem informasi akuntansi, budaya organisasi, kinerja individual.

\section{ABSTRACT}

Information technology is a necessity to demonstrate the work of the company. The role of organizational culture is expected to stimulate employee work discipline, in order to increase employee productivity. This study aims to determine the effect of the effectiveness of accounting information systems on individual performance with organizational culture as a moderator in the Village Credit Institutions in Tegallalang District. The population in this study amounted to 132 populations. The sample determination method uses saturated sampling technique so that the number of samples is 132 people. Data analysis techniques using Moderating Regression Analysis Test. The results of testing the first hypothesis shows that the variable effectiveness of accounting information systems has a positive effect on individual performance. The results of testing the second hypothesis indicate that organizational culture as a moderator is able to strengthen the effect of the effectiveness of the accounting information system on individual performance.

Keywords: effectiveness of accounting information systems, organizational culture, individual performance.

\section{PENDAHULUAN}


Dewa Ayu Ari Arma Bintang dan Ida Bagus Dharmadiaksa. Pengaruh...

Pesatnya perkembangan teknologi menyebabkan informasi dengan mudah sampai kepada masyarakat sehingga menjadikan sebagian besar masyarakat semakin merasakan informasi sebagai salah satu kebutuhan penting disamping kebutuhan lainnya. Teknologi informasi dengan komputer sebagai motor penggeraknya telah memudahkan segalanya. Teknologi informasi berkembang dengan pesat, sehingga memiliki dampak yang positif dan signifikan bagi perusahaan. Di Indonesia, penerapan teknologi informasi berbasis sistem informasi akuntansi sangat dibutuhkan agar bisnis dapat bersaing terutama dalam menghadapi ASEAN Economic Community (AEC) pada tahun 2016, khususnya untuk usaha mikro, kecil dan menengah (UMKM) (Bayu et al., 2016). Teknologi informasi dapat didefinisikan sebagai perpaduan antara beberapa teknologi berbasis komputer dan telekomunikasi, seperti perangkat keras, perangkat lunak, teknologi jaringan, database, dan peralatan telekomunikasi lainnya.

Sistem Informasi (SI) memiliki peran yang sangat penting di dalam bidang akuntansi, karena pada dasarnya tujuan utama akuntansi adalah menyediakan informasi untuk para pengambil keputusan. Secara umum semua perusahaan atau organisasi akan selalu membutuhkan informasi untuk mengambil sebuah keputusan. Informasi yang dibutuhkan haruslah informasi yang akurat, yang tersedia tepat waktu kapanpun dibutuhkan, dan memiliki nilai yang tepat dan relevan (Deny, 2014).

Informasi diharapkan mampu meningkatkan efektivitas sistem yang digunakan dalam perusahaan. Efektivitas adalah sautu gambaran atau ukuran 
seberapa jaut target dapat dicapai. Suatu sistem dapat dikatakan efektif apabila mampu menghasilkan informasi yang berkualitas dan mampu membantu kinerja penggunanya. Kualitas sistem informasi akuntansi dapat dievaluasi dari akurasi, ketepatan waktu, kelengkapan, dan konsistensi (Al-hiyari, 2013).

Sistem informasi akuntansi memiliki peranan yang sangat potensial dalam pengembangan dan penyediaan informasi sebagai pengendalian manajemen dan membantu dalam pengambilan sebuah keputusan. Penggunaan SIA tentunya harus diimbangi dengan budaya organisasi yang berlaku pada perusahaan. Budaya organisasi merupakan salah satu faktor internal yang diindikasikan berpengaruh terhadap kinerja perusahaan (Hanna dkk., 2013). Banyak perusahaan yang memiliki orang-orang berkemampuan intelektual yang baik namun seringkali kemampuan intelektual yang baik itu tidak terwujud dalam kinerja yang baik pula sehingga berdampak negatif terhadap perusahaan. Salah satu faktor penyebab yang paling utama adalah budaya organisasi yang buruk (Fajar dkk., 2017). Budaya itu sendiri merupakan hal yang sangat esensial bagi perusahaan atau organisasi karena akan selalu berhubungan dengan kehidupan yang ada didalam perusahaan (Siswoko, 2014). Budaya organisasi merupakan falsafah, ideologi, nilai-nilai, anggapan, harapan, keyakinan, sikap dan norma-norma yang dimiliki secara bersama dan mengikat dalam suatu organisasi tertentu.

Penelitian ini menggunakan konsep teori penelitian teknologi (Technology Acceptance Model) yaitu ada dua faktor yang menetukan niat dalam penggunaan sistem atau yang salah satunya yaitu persepsi kemanfaatan (perceived usefulness) 
Dewa Ayu Ari Arma Bintang dan Ida Bagus Dharmadiaksa. Pengaruh...

yang didefinisikan sebagai tingkat dimana seseorang percaya bahwa pengguna teknologi mampu meningkatkan kinerja. Konsep TAM yakin bahwa pengguna sistem informasi mampu meningkatkan kinerja individu atau suatu organisasi.

Keberhasilan perusahaan dalam mencapai sebuah tujuan dan memenuhi kebutuhan masyarakat sangat bergantung pada kinerja karyawan. Menyediakan laporan keuangan yang relevan dan reliabel yang dapat digunakan sebagai informasi dan dasar untuk pengambilan keputusan adalah upaya peningkatan kinerja individual dalam sudut pandang akuntansi. Kinerja individu adalah kemampuan individu untuk menyelesaikan suatu pekerjaan dengan berhasil dan efisien pada suatu perusahaan. Kinerja individual diharapkan dapat meningkatkan efektivitas SIA dengan bantuan teknologi dan menjadikan budaya organisasi sebagai acuan dalam bekerja, sehingga mampu mengoprasikan sistem informasi akuntansi dengan tepat dan akurat.

Lembaga keuangan mulai memanfaatkan Sistem Informasi Akuntansi berbasis komputer, salah satunya adalah Lembaga Perkreditan Desa. Lembaga Perkreditan Desa (LPD) merupakan badan usaha keuangan milik desa pekraman dimana lembaga ini melakukan kegiatan operasionalnya di lingkungan desa untuk melayani masyarakat desa setempat. LPD bertujuan untuk mendorong pembangunan ekonomi pada masyarakat desa melalui pemberian kredit maupun simpanan dalam bentuk tabungan.

Penelitian ini dilakukan pada Lembaga Perkreditan Desa yang berlokasi di Kecamatan Tegallalang. Sistem informasi akuntansi diharapkan dapat 
memudahkan pengolahan data pada LPD, karena aset yang semakin besar juga diikuti dengan meningkatnya volume transaksi keuangan, sehingga akan membutuhkan pengolahan data yang lebih praktis.

Peningkatan kinerja individual pengurus LPD sangat dibutuhkan untuk perkembangan LPD sehingga dapat bersaing dengan lembaga keuangan lainnya. Pemilihan pengurus LPD diputuskan berdasarkan paruman di desa pakraman LPD tersebut. Paruman adalah Pertemuan yang dilakukan oleh krama adat untuk membahas masalah tertentu yang keputusannya diambil berdasarkan musyawarah mufakat bersama. Jadi, pemilihan pengurus LPD tersebut tidak berdasarkan latar belakang pendidikan namun lebih mengutamakan kejujuran. Cara pemilihan karyawan inilah yang membuat LPD menjadi unik karena memiliki perbedaan dari lembaga keuangan yang lainnya.

LPD Kecamatan Tegallalang menerapkan budaya organisasi berupa filosofi Tri Hita Karana, yaitu tiga penyebab kesejahteraan (kebahagiaan) hidup. Tri Hita Karana sebagai penyebab kesejahteraan bersumber pada keharmonisan hubungan antara manusia dengan Tuhan (parahyangan), manusia dengan manusia (Pawongan), manusia dengan lingkungannya (Palemahan).

Penelitian ini menguji kembali pengaruh variabel efektivitas SIA pada variabel kinerja individual yang dimoderasi oleh budaya organisasi. Penelitian mengenai pengaruh efektivitas SIA terhadap kinerja individual telah dilakukan pada penelitian sebelumnya tetapi terjadi ketidakkonsistenan hasil penelitian mengenai hubungan tersebut. Hasil penelitan seperti pada penelitian Puja dan 
Dewa Ayu Ari Arma Bintang dan Ida Bagus Dharmadiaksa. Pengaruh...

Suardikha (2013), Marlinawati dan Suaryana (2013), Marlita dan Dharmadiaksa (2014), serta Mercika dan Jati (2015) menunjukan hasil bahwa efektivitas sistem informasi akuntansi berpengaruh positif dan signifikan terhadap kinerja individu dan karyawan. Namun sebaliknya disisi lain juga terdapat penelitian yang menunjukan bahwa pemakaian sistem informasi akuntansi tidak dapat meningkatkan profitabilitas, kinerja individu, dan efisiensi operasi seperti pada penelitian (Urqia et al., 2010), (Kouser et al., 2011) dan (Kharuddin et al., 2010). (Soudani, 2012) juga menemukan hasil penelitian yang menunjukan hasil yang tidak mendukung adanya hubungan yang positif antara sistem informasi akuntansi terhadap kinerja. Berdasarkan hal tersebut, perlu dilakukan penelitian mengenai pengaruh efektivitas sistem informasi akuntansi pada kinerja individual dengan budaya organisasi sebagai pemoderasi di Lembaga Perkreditan Desa Kecamatan Tegallalang.

Penelitian ini dilakukan bertujuan untuk mengetahui efektivitas sistem informasi akuntansi berpengaruh terhadap kinerja individual di Lembaga Perkreditan Desa Kecamatan Tegallalang dan untuk mengetahui budaya organisasi memoderasi pengaruh efektivitas sistem informasi akuntansi terhadap kinerja individual di Lembaga Perkreditan Desa Kecamatan Tegallalang. Penelitian ini diharapkan dapat digunakan sebagai pendukung teoritis atau menambah khasanah ilmu pengetahuan di bidang akuntansi khususnya mengenai sistem informasi akuntansi terhadap kinerja individual yang dimoderasi oleh budaya organisasi. 
Selain itu penelitian ini dapat menjadi acuan bagi mahasiswa yang akan melakukan penelitian pada bidang yang sama.

Teori tentang penggunaan teknologi sistem informasi dikenal dengan nama Technology Acceptance Model (TAM) yang mengasumsikan bahwa penggunaan sistem pada kenyataannya ditentukan oleh niat perilaku pengguna yang didasarkan pada persepi kebermanfaatan (Perceived Usefulness) dan kemudahan penggunaan (Perceived Ease of Use). TAM menyatakan bahwa secara keseluruhan prilaku manusia dapat dijelaskan dengan memertimbangkan kepercayaannya. Dapat dikatakan bahwa teknologi sistem informasi akan digunakan dengan baik oleh individu apabila sistem tersebut mudah digunakan serta menghasilkan manfaat dan menguntungkan dalam peningkatan kinerjanya.

Efektivitas sistem informasi akuntansi merupakan suatu ukuran yang memberikan gambaran sejauh mana target dapat dicapai dari suatu kumpulan sumber daya yang diatur untuk mengumpulkan, memroses, dan menyimpan data elektronik, kemudian mengubahnya menjadi sebuah informasi yang berguna serta menyediakan laporan formal yang dibutuhkan dengan baik secara kualitas maupun waktu. Konsep TAM yakin bahwa pengguna sistem informasi mampu meningkatkan kinerja individu atau suatu organisasi.

Hasil penelitian dari Suhud (2015), Aditya dan Suardikha (2013), Marlita dan Dharmadiaksa (2014), Suratini (2015) menyatakan bahwa efektivitas teknologi sistem informasi akuntansi berpengaruh positif dan signifikan terhadap kinerja karyawan. Sebaliknya, disisi lain juga terdapat penelitian yang menunjukan hasil 
Dewa Ayu Ari Arma Bintang dan Ida Bagus Dharmadiaksa. Pengaruh...

yang tidak mendukung adanya hubungan yang positif antara sistem informasi akuntansi terhadap kinerja individual (Soudani, 2012). Berdasarkan uraian diatas, maka rumusan hipotesis yang digunakan adalah:

$\mathrm{H}_{1}$ : Efektivitas sistem informasi akuntansi berpengaruh positif pada kinerja individual.

Menurut Yamin (2014) budaya organisasi merupakan kebiasaan-kebiasaan yang terjadi dalam hirarki organisasi yang mewakili norma-norma perilaku dan diikuti oleh para anggota dalam organisasi, maka budaya organisasi akan memberikan suasana psikologis bagi semua anggota, bagaimana mereka bekerja, bagaimana berhubungan dengan atasan maupun rekan sekerja dan bagaimana menyelesaikan masalah merupakan wujud budaya yang khas bagi setiap organisasi. Setiap organisasi sangat penting menerapkan budaya organisasi untuk ditaati oleh anggotanya. Budaya organisasi merupakan salah satu faktor internal yang diindikasikan berpengaruh terhadap kinerja perusahaan (Hanna dkk., 2013).

Ketahanan suatu perusahaan untuk terus maju dan berkembang dipengaruhi oleh faktor budaya organisasi (Pradiva dan Wardana, 2014). Nilai-nilai yang terkandung pada budaya organisasi tersebut digunakan sebagai pedoman oleh para anggota organisasi dalam menjalankan kegiatannya sesuai dengan tujuan organisasi. Budaya organisasi memiliki pengaruh yang besar pada perilaku anggota-anggotanya dalam mewujudkan strategi organisasi (Hariani, dkk. 2013). Dengan menerapkan budaya organisasi pada perusahaan, individu dapat memerbaiki perilaku dan sebagai motivasi kerja sumber daya manusia sehingga mampu meningkatkan kinerjanya. 
Budaya organisasi berperan penting dalam mengendalikan perilaku pengguna sistem informasi akuntansi untuk menghasilkan informasi, guna menciptakan laporan perencanaan yang akurat, tepat dan dapat dipercaya. Anggiriawan (2015) dalam penelitiannya menyimpulkan bahwa semakin tepat budaya organisasi yang dikembangkan, maka kinerja organisasi semakin berhasil. Hasil penelitian Shahzab, et al., (2012), menyatakan budaya organisasi dapat memengaruhi kinerja karyawan. Aripin, et al (2013), Awadh and Alyahya (2013), Adewale and Adeniji (2013), yang menganalisis pengaruh budaya organisasi pada kinerja individu membuktikan bahwa budaya organisasi memiliki pengaruh positif pada kinerja individual. Bertolak belakang dengan hasil penelitian tersebut, Sugiartini dan Dharmadiaksa (2016) menyatakan bahwa budaya organisasi tidak dapat memoderasi hubungan antara efektivitas teknologi sistem informasi akuntansi dengan kinerja individual. Berdasarkan uraian diatas, maka rumusan hipotesis yang digunakan adalah:

$\mathrm{H}_{2}$ : Budaya organisasi memerkuat pengaruh efektivitas sistem informasi akuntansi pada kinerja individual.

\section{METODE PENELITIAN}

Pendekatan yang digunakan dalam penelitian ini adalah pendekatan kuantitatif yang berbentuk asosiatif. Penelitian kuantitatif merupakan penelitian yang lebih menekankan pengujian teori melalui pengukuran variabel penelitian dengan angka serta data analisis menggunakan prosedur statistik (Indriantoro dan Supomo, 2013:12). Penelitian asosiatif merupakan penelitian yang bertujuan untuk mengetahui hubungan antara dua variabel atau lebih (Sugiyono, 2016:11). 


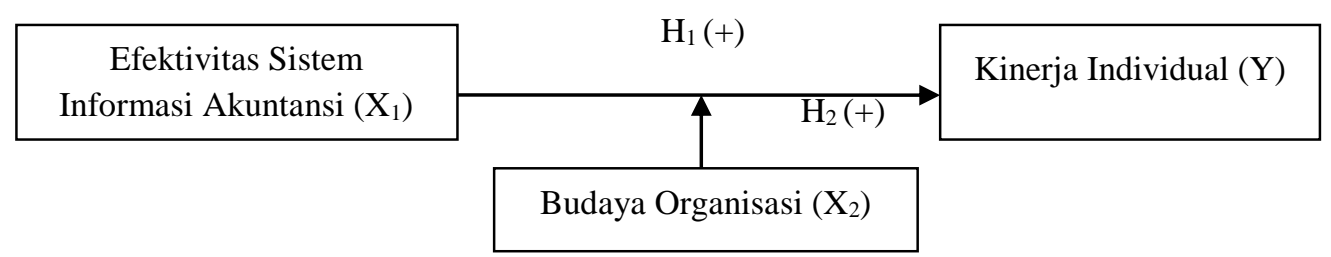

\section{Gambar 1. \\ Desain Penelitian}

Pada penelitian ini variabel yang diuji yaitu pengaruh efektivitas sistem informasi akuntansi pada kinerja individual yang dimoderasi oleh budaya organisasi. Penelitian ini dilakukan pada Lembaga Perkreditan Desa (LPD) di Kecamatan Tegallalang. Perkembangan lembaga keuangan yang pesat memicu persaingan ketat antara LPD dengan lembaga keuangan lainnya, untuk itu diperlukan sistem informasi akuntansi untuk meningkatkan kinerja LPD sehingga dapat bersaing dengan lembaga keuangan lainnya. Semula jumlah LPD di Kecamatan Tegallalang berjumlah 45 LPD karena satu LPD sudah tidak beroperasi, jumlah LPD di Kecamatan Tegallalang menjadi 44 LPD.

Variabel dependen adalah variabel yang dipengaruhi atau yang menjadi akibat karena adanya variabel bebas (Sugiyono, 2016:40). Dalam penelitian ini variabel dependen yang digunakan adalah kinerja individual. Kinerja individu adalah tingkat keberhasilan seseorang dalam pencapaian tujuan organisasi. Menyediakan laporan keuangan yang relevan dan reliabel yang dapat digunakan sebagai informasi dan dasar untuk pengambilan keputusan adalah upaya peningkatan kinerja individual dalam sudut pandang akuntansi. Terdapat lima indikator yang menjadi alat ukur kinerja individual (Andhika, 2007), yaitu kuantitas 
ISSN: 2302-8556

kerja (quantity), kualitas kerja (quality), ketepatan waktu (timeliness), pengawasan supervisor (need for supervisor), pengaruh rekan kerja (interpersonal impact).

Variabel independen adalah variabel yang memengaruhi atau yang menjadi sebab perubahannya atau timbulnya variabel dependen (Sugiyono, 2016:39). Dalam penelitian ini variabel independen yang digunakan adalah efektivitas sistem infomasi akuntansi. Efektivitas sistem informasi akuntansi merupakan suatu ukuran yang memberikan gambaran sejauh mana target dapat dicapai dari suatu kumpulan sumber daya yang diatur untuk mengumpulkan, memroses, dan menyimpan data elektronik, kemudian mengubahnya menjadi sebuah informasi yang berguna serta menyediakan laporan formal yang dibutuhkan dengan baik secara kualitas maupun waktu. Model pengukuran efektivitas sistem informasi akuntansi (Aditya dan Suardikha, 2013) terdiri dari enam indikator, yaitu system quality, information quality, service quality, information use, user satisfaction, net benefit.

Variabel moderasi, yaitu variabel yang dapat memerkuat dan memerlemah hubungan antara variabel independen dengan variabel dependen (Sugiyono, 2016:40). Variabel moderasi dalam penelitian ini adalah budaya organisasi. Budaya organisasi adalah sebuah tradisi yang dianut oleh seluruh anggota organisasi atau perusahaan yang digunakan sebagai konsep dalam menyusun strategi atau pengembangan organisasi yang dipimpin (Ria dan Suartana, 2014). Indikator budaya organisasi yang dikemukakan Denison (1990), yaitu organisasi dengan menampilkan gabungan sifat budaya organisasi berdasarkan efektivitas organisasi yang diantaranya terdiri dari empat dimensi, yaitu keterlibatan (involvement), 
Dewa Ayu Ari Arma Bintang dan Ida Bagus Dharmadiaksa. Pengaruh...

konsistensi (consistency), adaptabilitas (adaptability), misi (mission). Pengukuran masing-masing variabel efektivitas sistem informasi akuntansi, kinerja individual dan budaya organisasi dilakukan dengan menggunakan kuesioner skala likert dengan skala yang digunakan yaitu skala 4 poin.

Populasi dalam penelitian ini adalah karyawan yang secara langsung menggunakan sistem informasi akuntansi yaitu, kepala LPD, bendahara dan tata usaha yang berjumlah 132 populasi dari 44 LPD yang ada di Kecamatan Tegallalang. Sampel adalah bagian dari jumlah dan karakteristik yang dimiliki oleh populasi. Sampel yang diambil menggunakan teknik sampling jenuh, yaitu teknik penentuan sampel bila semua anggota populasi digunakan sebagai sampel (Sugiyono, 2016:96). Kriteria dalam pemilihan sampel pada penelitian ini adalah karyawan yang secara langsung menggunakan sistem informasi akuntansi di LPD se-Kecamatan Tegallalang yaitu kepala LPD, bendahara, dan tata usaha. Jadi jumlah sampel dalam penelitian ini adalah sebanyak 132 karyawan.

Jenis data yang digunakan dalam penelitian ini adalah data kuantitatif dan data kualitatif. Data kuantitatif berupa hasil kuesioner, jumlah aset Lembaga Perkreditan Desa, dan jumlah karyawan Lembaga Perkreditan Desa di Kecamatan Tegallalang. Data kualitatif yang digunakan dalam penelitian ini berupa daftar Lembaga Perkreditan Desa di Kecamatan Tegallalang dan job description. Sumber data yang digunakan dalam penelitian ini adalah data primer dan data sekunder. Data primer dalam penelitian ini adalah jawaban responden terhadap pernyataan kuesioner yang dikumpulkan dari Lembaga Perkreditan Desa di Kecamatan 
Tegallalang. Data sekunder dalam penelitian ini adalah data mengenai daftar Lembaga Perkreditan Desa di Kecamatan Tegallalang.

Metode pengumpulan data yang digunakan dalam penelitian ini adalah dengan wawancara dan kuesioner. Wawancara yaitu teknik pengumpulan data yang digunakan apabila peneliti ingin melakukan studi pendahuluan untuk menemukan permasalahan yang harus diteliti dan juga apabila peneliti ingin mengetahui hal-hal dari responden yang lebih mendalam melalui tanya jawab dan jumlah respondennya sedikit atau kecil (Sugiyono, 2016:157). Wawancara dalam penelitian ini dilakukan dengan kepala LPD, bendahara dan tata usaha pada Lembaga Perkreditan di Kecamatan Tegallalang. Kuesioner yaitu teknik pengumpulan data yang dilakukan dengan cara memberi seperangkat pertanyaan atau pernyataan tertulis kepada responden untuk dijawab (Sugiyono, 2016:162). Kuesioner dalam penelitian ini disebarkan langsung di seluruh LPD Kecamatan Tegallalang dan ditujukan kepada kepala LPD, bendahara dan tata usaha di Lembaga Perkreditan Desa Kecamatan Tegallalang.

Teknik analisis data yang digunakan dalam penelitian ini adalah uji analisis koefisien regresi menggunakan uji Moderating Regression Analysis (MRA) yang merupakan analisis yang menggunakan pendekatan analitik yang mepertahankan integritas sampel dan memberikan dasar untuk mengontrol pengaruh variable moderator (Ghozali, 2016:219). Persamaan statistik yang digunakan adalah:

$Y=\alpha+\beta_{1} X_{1}+\beta_{2} X_{2}+\beta_{3} X_{1} X_{2}+\varepsilon$

Keterangan:

$\mathrm{Y} \quad=$ kinerja individual 
Dewa Ayu Ari Arma Bintang dan Ida Bagus Dharmadiaksa. Pengaruh...

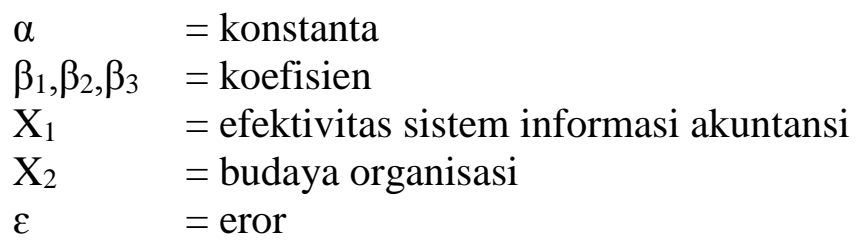

\section{HASIL DAN PEMBAHASAN}

Penelitian ini dilakukan untuk mengetahui pengaruh efektivitas sitem informasi akuntansi pada kinerja individual dengan budaya organisasi sebagai pemoderasi. Data dikumpulkan dengan menyebarkan kuesioner ke Lembaga Perkreditan Desa di Kecamatan Tegallalang. Penelitian ini telah menyebarkan kuesioner sebanyak 132 kuesioner dengan tingkat pengembalian responden sebesar 100 persen, dan tingkat penggunaan sebesar 100 persen, yang disajikan pada Tabel 1. sebagai berikut.

Tabel 1.

Rincian Penyebaran dan Pengembalian Kuesioner

\begin{tabular}{lc}
\hline \multicolumn{1}{c}{ Uraian } & Jumlah Kuesioner \\
\hline Total Kuesioner yang disebar & 132 \\
Kuesioner tidak kembali & 0 \\
Kuesioner yang dikembalikan & 132 \\
Kuesioner yang gugur & 0 \\
Kuesioner yang digunakan & 132 \\
\hline Tingkat Pengembalian (response rate $)=132 / 132 \times 100 \%$ & $100 \%$ \\
Tingkat penggunaan (usable respon rate) $=132 / 132 \times 100 \%$ & $100 \%$ \\
\hline
\end{tabular}
Sumber: Data diolah 2018

Berdasarkan Tabel 1. menunjukkan bahwa jumlah kuesioner yang disebar sebanyak 132 kuesioner dan dikembalikan oleh responden sebanyak 132 kuesioner dan setelah diperiksa semua kuesioner dapat digunakan karena telah diisi dengan 
ISSN: 2302-8556

lengkap dan memenuhi kriteria. Setiap Lembaga Perkreditan Desa di Kecamatan Tegallalang masing-masing mendapatkan 3 kuesioner dimana terdapat 44 LPD di Kecamatan Tegallalang.

Pengujian validitas dilakukan dengan menghitung nilai pearson correlation. Menurut Sugiyono (2014:118), suatu instrumen dikatakan valid apabila nilai r pearson correlation terhadap skor total diatas 0,3 . Berdasarkan hasil uji validitas menunjukkan bahwa seluruh indikator pernyataan dalam variabel Efektivitas Sistem Informasi Akuntansi $\left(\mathrm{X}_{1}\right)$, Budaya Organisasi $\left(\mathrm{X}_{2}\right)$, dan Kinerja Individual (Y) memiliki pearson correlation yang lebih besar dari r-tabel untuk 132 responden sehingga seluruh indikator tersebut telah memenuhi syarat validitas data.

Pengujian reliabilitas menunjukkan sejauh mana suatu alat pengukur dapat dipercaya atau dapat diandalkan. Uji ini dilakukan terhadap instrumen dengan Cronbach's Alpha, apabila lebih besar dari 0,70 maka instrumen yang digunakan reliabel. Berdasarkan hasil uji reliabilitas dalam penelitian ini menunjukkan bahwa seluruh indikator pernyataan dalam variabel Efektivitas Sistem Informasi Akuntansi $\left(\mathrm{X}_{1}\right)$, Budaya Organisasi $\left(\mathrm{X}_{2}\right)$, dan Kinerja Individual $(\mathrm{Y})$ memiliki nilai Cronbach's Alpha lebih besar dari 0,7 sehingga pernyataan pada kuesioner tersebut reliabel.

Analisis statistik deskriptif dipergunakan untuk menggambarkan atau menjelaskan suatu data pada variabel penelitian. Analisis statistik deskriptif dilihat berdasarkan nilai rata-rata (mean), standar deviasi, nilai maximum, dan nilai minimum. Berikut merupakan statistik deskriptif dari penelitian ini: 
Tabel 2.

Hasil Uji Analisis Statistik Deskriptif

\begin{tabular}{cccccc}
\hline Variabel & N & Minimum & Maximum & Mean & Std. Deviation \\
\hline X1 & 132 & 8,00 & 31,00 & 24,20 & 6,39 \\
X2 & 132 & 9,00 & 35,58 & 17,08 & 6,88 \\
Y & 132 & 6,00 & 22,87 & 17,86 & 4,93 \\
\hline
\end{tabular}

Sumber: Data diolah 2018

Berdasarkan Tabel 2. dapat dilihat bahwa variabel kinerja individual (Y) memiliki nilai minimum sebesar 6,00 ; nilai maksimum sebesar 22,87 ; rata-rata sebesar 17,86; dan simpangan baku sebesar 4,93. Ini berarti bahwa terjadi perbedaan nilai kinerja individual yang diteliti terhadap nilai rata-ratanya sebesar 4,93. Variabel Efektivitas SIA $\left(\mathrm{X}_{1}\right)$ memiliki nilai minimum sebesar 8,00; nilai maksimum sebesar 31,00; rata-rata sebesar 24,20; dan simpangan baku sebesar 6,39. Ini berarti bahwa terjadi perbedaan nilai efektivitas SIA yang diteliti terhadap nilai rata-ratanya sebesar 6,39 . Variabel Budaya Organisasi $\left(\mathrm{X}_{2}\right)$ memiliki nilai minimum sebesar 9,00; nilai maksimum sebesar 35,58; rata-rata sebesar 17,08; dan simpangan baku sebesar 6,88 . Ini berarti bahwa terjadi perbedaan nilai budaya organisasi yang diteliti terhadap nilai rata-ratanya sebesar 6,88 .

Uji normalitas bertujuan untuk mengetahui apakah dalam residual dari model regresi yang dibuat berdistribusi normal atau tidak. Untuk menguji apakah data yang digunakan normal atau tidak dapat dilakukan dengan menggunakan uji Kolmogorov Smirnov. Apabila koefisien Asymp. Sig. (2-tailed) lebih besar dari 0,05 maka data tersebut dikatakan berdistribusi normal. Hasil uji normalitas pada penelitian ini menunjukkan nilai Asymp. Sig. (2-tailed) 0,200. Hasil tersebut mengindikasikan bahwa model persamaan regresi tersebut berdistribusi normal 
karena nilai Asymp. Sig. (2-tailed) lebih besar dari nilai alpha 0,05 atau Asymp.Sig $>0,05$.

Uji heteroskedastisitas bertujuan untuk mengetahui apakah dalam model regresi terjadi ketidaksamaan varians dari residual satu pengamatan ke pengamatan yang lain dan pengujian ini dilakukan dengan uji Glejser. Jika tidak ada satu pun variabel bebas yang berpengaruh signifikan terhadap nilai absolute residual atau nilai signifikansinya diatas 0.05 maka tidak mengandung gejala heteroskedastisitas. Hasil uji heteroskedastisitas pada penelitian ini menunjukkan bahwa nilai Sig. dari seluruh variabel lebih besar dari 0,05 yang berarti tidak terdapat pengaruh antara variabel bebas terhadap absolute residual. Dengan demikian, model yang dibuat tidak mengandung gejala heteroskedastisitas.

Uji Moderating Regression Analysis (MRA) bertujuan untuk menguji hubungan antara pengaruh antara satu variabel independen dengan dependen. Uji ini digunakan untuk mengetahui pengaruh efektivitas sistem informasi akuntansi $\left(\mathrm{X}_{1}\right)$ pada kinerja individual $(\mathrm{Y})$ yang di moderasi oleh budaya organisasi $\left(\mathrm{X}_{2}\right)$ di Lembaga Perkreditan Desa Kecamatan Tegallalang. Hasil pengujian dapat dilihat dalam Tabel 3. berikut ini:

Tabel 3.

Hasil Uji Moderating Regression Analysis (MRA)

\begin{tabular}{llcccc}
\hline Variabel Terikat & \multicolumn{1}{c}{$\begin{array}{c}\text { Variabel } \\
\text { Bebas }\end{array}$} & $\begin{array}{c}\text { Koefisien } \\
\text { Regresi }\end{array}$ & $\begin{array}{c}\text { Standar } \\
\text { Error }\end{array}$ & t- hitung & Sig. \\
\hline \multirow{2}{*}{ Kinerja Individual } & $\mathrm{X} 1$ & 0,645 & 0,037 & 17,391 & 0,000 \\
& $\mathrm{X} 2$ & $-0,504$ & 0,114 & $-4,433$ & 0,000 \\
& $\mathrm{X} 1 \_\mathrm{X} 2$ & 0,012 & 0,005 & 2,180 & 0,031 \\
\hline Constanta & $=18,200$ & \multicolumn{3}{c}{ F-Hitung } & $=134,490$ \\
Adjusted R Square & $=0,754$ & Sig. & $=0,000$ & \\
Sumber: Data diolah 2018 & &
\end{tabular}


Dewa Ayu Ari Arma Bintang dan Ida Bagus Dharmadiaksa. Pengaruh...

Nilai konstanta 18,200 memiliki arti apabila efektivitas sistem informasi akuntansi, budaya organisasi, hubungan antara efektivitas sistem informasi akuntansi dengan budaya organisasi konstan, maka kinerja individual meningkat sebesar 18,200 satuan.

Nilai koefisien regresi efektivitas sistem informasi akuntansi $\left(\mathrm{X}_{1}\right)$ sebesar 0,645 memiliki arti apabila efektivitas sistem informasi akuntansi meningkat sebesar 1 satuan dengan anggapan variabel lainnya konstan, maka kinerja individual meningkat sebesar 0,645 satuan. Nilai koefisien regresi budaya organisasi $\left(\mathrm{X}_{2}\right)$ sebesar $-0,504$ memiliki arti apabila pemahaman mengenai budaya organisasi meningkat sebesar 1 satuan dengan anggapan variabel lainnya konstan, maka kinerja individual menurun sebesar 0,504 satuan. Nilai koefisien regresi $\mathrm{X}_{1} \_\mathrm{X}_{2}$ sebesar 0,012 mengindikasikan bahwa apabila hubungan efektivitas sistem informasi akuntansi dengan budaya organisasi meningkat 1 satuan, maka kinerja individual meningkat sebesar 0,012 satuan.

Hasil analisis model pada Tabel 3. menunjukkan bahwa nilai Adjusted $\mathrm{R}^{2}$ sebesar 0,754. Hal ini berarti 75,4 persen variabel kinerja individual mampu dijelaskan oleh variabel efektivitas sistem informasi akuntansi serta budaya organisasi sebagai variabel moderasi, sedangkan sisanya sebesar 24,6 persen dijelaskan oleh faktor-faktor lain yang tidak dijelaskan di dalam model. Berdasarkan Tabel 3. satu hal yang perlu diperhatikan adalah kelayakan model penelitian yang dilakukan dengan uji $\mathrm{F}$ untuk mengetahui pengaruh variabelvariabel independen pada variabel dependen. Jika nilai sig $\mathrm{F}<(\alpha=0,05)$ berarti 
variabel independen memengaruhi variabel dependen dan variabel independen layak digunakan untuk memrediksi variabel dependen, sehingga pembuktian hipotesis dapat dilanjutkan.

Berdasarkan output pada Tabel 3. nilai dari F hitung 134,490 dengan nilai signifikansi 0.000 (lebih kecil dari 0.05) maka disimpulkan bahwa ada pengaruh yang signifikan dari variabel independen terhadap variabel dependen secara simultan (bersama-sama). Sehingga model regresi moderasi layak digunakan sebagai alat analisis untuk menguji pengaruh variabel independen terhadap variabel dependen yang dipengaruhi oleh variabel moderasi.

Berdasarkan hasil yang disajikan pada Tabel 3. menunjukkan bahwa variabel efektivitas sistem informasi akuntansi memiliki nilai koefisien regresi sebesar 0,645 dengan tingkat signifikansi sebesar 0,000 lebih kecil dari nilai taraf nyata 0,05 sehingga dapat disimpulkan bahwa efektivitas sistem informasi akuntansi berpengaruh positif pada kinerja individual. Hal tersebut menunjukkan bahwa semakin efektif sistem informasi akuntansi yang dimiliki pada LPD maka akan semakin baik kinerja individual dari karyawan tersebut. Dengan demikian maka dapat dinyatakan bahwa hipotesis pertama $\left(\mathrm{H}_{1}\right)$ dalam penelitian ini diterima. Hasil penelitian ini sesuai dengan penelitian yang dilakukan oleh Sugiartini (2016) yang menyatakan bahwa efektivitas sistem informasi akuntansi berpengaruh positif terhadap kinerja individual. Berdasarkan teori TAM, jika setiap karyawan pengguna SIA mampu menerima manfaat dan merasakan kemudahan dari adanya suatu sistem informasi akuntansi, maka kinerja tentu akan dipermudah dengan 
Dewa Ayu Ari Arma Bintang dan Ida Bagus Dharmadiaksa. Pengaruh...

adanya suatu sistem tersebut. Hasil penelitian dari Suhud (2015), Aditya dan Suardikha (2013), Marlita dan Dharmadiaksa (2014), Suratini (2015) menyatakan bahwa efektivitas teknologi sistem informasi akuntansi berpengaruh positif dan signifikan terhadap kinerja karyawan.

Berdasarkan hasil yang di sajikan pada Tabel 3. menunjukkan bahwa variabel moderasi budaya organisasi memiliki nilai koefisien regresi sebesar 0,012 dengan tingkat signifikansi sebesar 0,031 lebih kecil dari nilai taraf nyata 0,05 sehingga dapat disimpulkan bahwa variabel moderasi budaya organisasi mampu memoderasi pengaruh efektivitas sistem informasi akuntansi pada kinerja individual. Hal tersebut menunjukkan bahwa dengan meningkatnya pemahaman mengenai budaya organisasi mampu memerkuat pengaruh efektivitas sistem informasi akuntansi pada kinerja individual. Dengan demikian maka dapat dinyatakan bahwa hipotesis kedua $\left(\mathrm{H}_{2}\right)$ dalam penelitian ini diterima.

Budaya organisasi memiliki pengaruh yang besar pada perilaku anggotaanggotanya dalam mewujudkan strategi organisasi (Hariani, dkk. 2013). Dengan menerapkan budaya organisasi pada perusahaan, individu dapat memerbaiki perilaku dan sebagai motivasi kerja sumber daya manusia sehingga mampu meningkatkan kinerjanya. Budaya organisasi berperan penting dalam mengendalikan perilaku pengguna sistem informasi akuntansi untuk menghasilkan informasi, guna menciptakan laporan perencanaan yang akurat, tepat dan dapat dipercaya. 
Anggiriawan (2015) dalam penelitiannya menyimpulkan bahwa semakin tepat budaya organisasi yang dikembangkan, maka kinerja organisasi semakin berhasil. Hasil penelitian Shahzab, et al., (2012), menyatakan budaya organisasi dapat memengaruhi kinerja karyawan. Aripin, et al (2013), Awadh and Alyahya (2013), Adewale and Adeniji (2013), yang menganalisis pengaruh budaya organisasi pada kinerja individu membuktikan bahwa budaya organisasi memiliki pengaruh positif pada kinerja individual.

Hasil penelitian ini memberikan tambahan informasi mengenai bagaimana budaya organisasi memoderasi pengaruh efektivitas sistem informasi akuntansi pada kinerja individual pada Lembaga Perkreditan Desa di Kecamatan Tegallalang. Terdapat bukti empiris yang diperoleh melalui penelitian ini yang menunjukkan bahwa budaya organisasi memperkuat pengaruh efektivitas sistem informasi akuntansi pada kinerja individual. Hal ini menunjukkan semakin tinggi pemahaman pegawai mengenai efektivitas sistem informasi akuntansi yang didukung dengan pemahaman mengenai budaya organisasi maka semakin meningkat kinerja individual pegawai tersebut. Hal ini didukung dengan adanya teori Technology Acceptance Model (TAM) yang mengasumsikan bahwa seorang individu akan menggunakan teknologi sistem informasi dengan baik apabila sistem tersebut mudah digunakan serta menghasilkan manfaat dan menguntungkan dalam peningkatan kinerjanya.

\section{SIMPULAN}


Berdasarkan hasil analisis yang diperoleh dalam penelitian ini, maka dapat disimpulkan sebagai berikut: 1) Tingkat efektivitas sistem informasi akuntansi berpengaruh positif dan signifikan pada kinerja individual di Lembaga Perkreitan Desa Kecamatan Tegallalang. Semakin tinggi efektivitas sistem informasi akuntansi, maka semakin tinggi kinerja individual; 2) Budaya organisasi memerkuat pengaruh efektivitas sistem informasi akuntansi pada kinerja individual. Semakin baik pemahaman pemakai sistem terhadap budaya organisasi, maka akan meningkatkan efektivitas sistem informasi akuntansi sehingga kinerja individual akan meningkat.

Berdasarkan simpulan diatas, saran yang dapat direkomendasikan bagi peneliti selanjutnya disarankan untuk memerluas ruang lingkup wilayah penelitian tidak hanya pada Lembaga Perkreditan Desa melainkan bisa juga pada perusahaan lainnya yang berbeda, agar lebih mampu melakukan generalisasi pada hasil penelitian. Peneliti selanjutnya juga dapat menggunakan metode pengukuran variabel budaya organisasi berbasis Tri Hita Karana atau mengganti variabel moderasi yang lain seperti tingkat pendidikan, insentif ataupun lainnya dan menambah variabel lain yang mungkin berhubungan dengan penelitian mengenai aspek keperilakuan sistem informasi akuntansi.

\section{REFERENSI}

Adewale, O.O., Anthonia, A.A. 2013. Impact of Organizational Culture on Human Resource Practices: A Study of Selected Nigerian Private Universities. Journal of Competitiveness. 5(4), pp: 115-133. 
Aditya, Puja Pratama. dan Suardikha, I Md. Sadha. 2013. Keahlian Pemakai Komputer dan Kenyamanan Fisik Memoderasi Pengaruh Efektivitas Sistem Informasi Akuntansi Terhadap Kinerja Karyawan di PT. Bank Sinar Harapan Bali Denpasar. E-Jurnal Akuntansi Universitas Udayana. 5(2), pp: 361-381.

Al-hiyari, Ahmad. 2013. Factors that Affect Accounting Information System Implementation and Accounting Information Quality: A Survey in University Utara Malaysia. American Journal of Economics 2013. 3(1), pp: 27-31.

Andhika, Wisnu. 2007. Pengaruh Persepsi Karyawan tentang Implementasi Sistem Informasi Akuntansi Berbasis Komputer terhadap Kinerja. Skripsi pada Universitas Brawijaya.

Anggiriawan, Putu Budi. 2015. Pengaruh Gaya Kepemimpinan dan Budaya Organisasi Terhadap Kinerja Organisasi dengan Penerapan Good Governance Sebagai Variabel Moderasi. Tesis. Universitas Udayana.

Aripin Ubud, S., Margono, S., Djumahir. 2013. Implication of Organizational Culture and Leadership Style the Effects on Job Satisfaction and Organizational Performance of Police Sector in Bandung, Cimahi, GarutWest Java. Journal of Business and Management. 7(5), pp: 44-49.

Awadh, A.M., Saad, A.M. 2013. Impact of Organizational Culture on Employee Performance. Journal International Review of Management and Business Research. 2(1).

Bayu Diatmika, I Wayan, Irianto, Gugus, Baridwan, Zaki. 2016. Determinants of Behavior Information Systems Based Information Technology Acceptance. Imperial Journal of Interdiciplinary Research (IJIR). 2(8), pp: 125

Budi Anggiriawan, Putu, Wirakusuma, Made Gede. 2015. Pengaruh Gaya Kepemimpinan dan Budaya Organisasi Terhadap Kinerja Organisasi Dengan Penerapan Good Governance Sebagai Variabel Moderasi. E-Jurnal Akuntansi Universitas Udayana. 10(2), pp: 312-316.

Denison, Daniel R. 1990. Corporate Culture and Organizational Effectiveness. New York: John Wiley and Sons.

Deny Larasdiputra, Gde dan Suryanawa, I Ketut. 2014. Penerapan Sistem Informasi Akuntansi Pada Bank Perkreditan Rakyat Sari Jaya Sedana Klungkung. 
Fajar Andika Karma, Kadek, Gerianta Wirawan Yasa, Dwi Ratnadi, Ni Made. 2017. Pengaruh Gaya Kepemimpinan Situasional, Budaya Organisasi dan Motivasi Pada Kinerja Karyawan di PT Bank Pembangunan Daerah Bali Cabang Badung. E-Jurnal Akuntansi Universitas Udayana. 19(2), pp: 888.

Ghozali, Imam. 2016. Aplikasi Analisis Multivariate dengan Program IMB SPSS23. Edisi Kedelapan. Semarang: Badan Penerbit Universitas Diponegoro.

Hanna Lestari, Andi Rahadian Wijaya, Subayo. 2013. Pengukuran Budaya Organisasi Pada Industri Minuman di Jawa Tengah Untuk Meningkatkan Daya Saing di Era Global, Jurnal Teknik Universitas Wahid Hasyim Semarang. X(4), pp: 21.

Hariani, D., Purbandari, T., dan Mujilan, A. 2013. Dukungan Manajerial dan Budaya Organisasi untuk Menuju Efektivitas Sistem Informasi. JRMA| Jurnal Riset Manajemen dan Akuntansi. 1(2), 29-36.

Indriantoro, N. dan Supomo, B. 2013. Metodologi Penelitian Bisnis. Yogyakarta: BPFE.

Kharuddin, S., Nassir, M.A., and M.Z. Ashhari. 2010. Information System and Firms' Performance: The Case of Malaysian Small Medium Enterprises. International business research. 3(4), 33.

Kouser, R., Awan, Shahzad, F., and A., Rana, G. 2011. Firm Size, Leveragee and Profitability: Overriding Impact of Accounting Information System. Journal of Management and Business Review. 1(10), pp: 58-64.

Marlinawati, Ni Made Ayu, dan Suaryana, Gusti Ngurah Agung. 2013. Pengaruh Penggunaan Teknologi Informasi, Efektivitas Sistem Informasi Akuntansi, Kepercayaan Atas Sistem Informasi Akuntansi, dan Kesesuaian Tugas pada Kinerja Karyawan Lembaga Perkreditan Desa di Kabupaten Badung. EJurnal Akuntansi Universitas Udayana. pp: 388-401.

Marlita, Ni Made Puji Astuti, dan Dharmadiaksa, Ida Bagus. 2014. Pengaruh Efektivitas Penerapan Sistem Informasi Akuntansi, Pemanfaatan dan Kesesuaian Tugas pada Kinerja Karyawan. E-Jurnal Akuntansi Universitas Udayana. 9(2). pp: 373-384.

Mercika, Ni Luh Dewi Tresna, Jati, I Ketut. 2015. Kemudahan Penggunaan Sistem Sebagai Moderasi Pengaruh Efektivitas Sistem Informasi Akuntansi pada Kinerja. E-Jurnal Akuntansi Universitas Udayana. 10(3), pp: 723-737. 
Pradiva Putra Salain, Putu, Wardana, Made. 2014. Pengaruh Kepemimpinan Terhadap Budaya Organisasi, Inovasi dan Kinerja Karyawan (Studi Kasus Pada KANWIL) PT. Pegadaian (PERSERO) Denpasar. Jurnal Buletin Studi Ekonomi. 19(1), pp: 70.

Ria Satyawati, Ni Made, Suartana, I Wayan. 2014. Pengaruh Budaya Organisasi Terhadap Kepuasan Kerja Yang Berdampak Pada Kinerja Keuangan. EJurnal Akuntansi Universitas Udayana. 6(1), pp: 17-32.

Shahzab, F., Luqman, R.A., Khan, A.R., \& Shabbir, L. 2012. Impact of Organizational Culture on Organizational Performance: An Overview. Interdiciplinary Journal Contemporary Research in Business. 3(9), pp: 975985.

Siswoko Wibowo, Ahmad. 2014. Pengaruh Budaya Organisasi, Kepuasan Kerja dan Gaya Kepemimpinan Terhadap Kinerja Karyawan. Jurnal Manajemen Universitas Dian Nuswanto. pp: 2.

Soudani, Siamak Nejadhosseini. 2012. The Usefulness of an Accounting Information System for Effective Organisational Performance. International Journal of Economics and Finance. 4 (5), pp: 136-145.

Sugiartini, Ni Made, dan Dharmadiaksa, Ida Bagus. 2016. Pengaruh Efektivitas Sistem Informasi Akuntasi Terhadap Kinerja Individual dengan Budaya Organisasi sebagai Pemoderasi. E-Jurnal Akuntansi Universitas Udayana. 14 (3), pp: 1867-1894.

Sugiyono. 2014. Metode Penelitian Pendidikan Pendekatan Kuantitatif, Kualitatif, dan $R \& D$. Bandung: Alfabeta.

2016. Metode Penelitian Administrasi. Bandung: Alfabeta.

2016. Metode Penelitian Pendidikan Pendekatan Kuantitatif, Kualitatif, dan $R \& D$. Bandung: Alfabeta.

Suhud, Sheilla Puteri. 2015. Pengaruh Penerapan Sistem Informasi Akuntansi Terhadap Kinerja Individu Pegawai Disro di Kota Bandung. Skripsi S-1 Jurusan Akuntansi Universitas Diponegoro.

Suratini, Ni Putu Eka, Sinarwati, Ni Kadek, Atmaja, Anantawirakrama Tungga. 2015. Pengaruh Efektivitas Sistem Informasi Akuntansi dan Pembangunan Teknologi Informasi Akuntansi Terhadap Kinerja Individual Pada PT. Bank Pembangunan Daerah Bali Kantor Cabang Singaraja. E-Jurnal Akuntansi 
Dewa Ayu Ari Arma Bintang dan Ida Bagus Dharmadiaksa. Pengaruh...

Universitas Pendidikan Ganesha. vol.3 no.1. Small Business. 1(1/2), pp: 119.

Yamin, Muh. 2014. Pola Budaya dan Kinerja Organisasi Publik (Studi Pada Pemerintah Kota Kendari). Jurnal Birokrat Ilmu Administrasi Publik. 1(2). 